\title{
PENENTUAN MODEL HUBUNGAN KEPADATAN PENDUDUK DAN FAKTORNYA MENGGUNAKAN METODE FORWARD SELECTION
}

\author{
(DETERMINING POPULATION DENSITY AND THE FACTORS \\ MODELS BY USING FORWARD SELECTION METHOD)
}

\author{
Puji Subekti $^{1}$, Mufidatul Islamiyah ${ }^{2}$ \\ STMIK ASIA MALANG,pujisubekti88@gmail.com \\ STMIK ASIA MALANG, mufidatu1014@gmail.com
}

\begin{abstract}
Abstrak
Kepadatan penduduk adalah perbandingan antara jumlah penduduk yang tinggal di wilayah tertentu dengan luas wilayahnya. Kota Blitar adalah salah satu Kota di Jawa Timur dengan kepadatan penduduk tinggi. Banyak faktor yang mempengaruhi kepadatan penduduk suatu daerah. Dalam penelitian ini menggunakan metode Forward Selection untuk menentukan model hubungan kepadatan penduduk Kota Blitar dan faktornya.Data sekunder yang digunakan adalah data jumlah penduduk datang, penduduk pindah, penduduk mati, penduduk lahir, dan luas wilayah.Hasil pengolahan data kepadatan penduduk dan faktor-faktor yang mempengaruhinya mengalami kasus multikolinieritas. Diperoleh model persamaan regresi yang terbaik yaitu $Y=5036+10.1 X_{1}+33 X_{3}-2217 X_{5}$ dengan $R-S q=$ $86,42 \%$. Hasil penelitian menunjukkan bahwa faktor-faktor yang paling berpengaruh terhadap kepadatan penduduk di Kota Blitar khususnya adalah jumlah penduduk pindah, penduduk mati, dan luas wilayah.
\end{abstract}

Kata kunci:Kepadatan Penduduk, Forward Selection

\begin{abstract}
Population density is the ratio between the number of people living in a particular area to the total area. Blitar City is one of the cities in East Java with a high population density.Many factors affect population density. This study uses the Forward Selection method to determine population density and the factors models of Blitar City. Secondary data includes the number of people coming, people moving out, people dying, people being born, and area. The results show a multicollinearity case. The best regression model is $Y=5036+$ $10.1 X_{1}+33 X_{3}-2217 X_{5}$ with $R-S q=86.42 \%$. The factors that most influence population density in the city of Blitar are the number of people moving, people dying, and area.
\end{abstract}

Keywords:Population density, Forward Selection

\section{PENDAHULUAN}

Kepadatan penduduk di Jawa Timur yang mencapai urutan terbesar kedua di Indonesia ini merupakan salah satu permasalahan yang harus diperhatikan pemerintah. Karena kepadatan penduduk yang semakin padat memiliki dampak 
yang bisa dirasakan oleh masyarakat. Diantaranya adalah banyaknyapenganguran, terjadinya kelaparan, kurangnya tempat tinggal, dan masih banyak lagi dampak lainnya. Oleh karena itu perlu diketahui faktor-faktor yang berpengaruh terhadap kepadatan penduduk itu sendiri, sehingga pemerintah dapat mengambil tindakan lebih lanjut untuk mencegah dampak yang tidak diinginkan. Faktor-faktor tersebut adalah jumlah penduduk datang, penduduk pindah, penduduk mati, penduduk lahir, dan luas wilayah. Hubungan antara kepadatan penduduk dengan semua faktor-faktorya dapat digambarkan dengan analisis regresi.

Dalam menghasilkan model persamaan yang baik, dalam persamaan regresi linier berganda tidak boleh terjadi multikolinieritas (ketergantungan antar peubah bebas). Untuk mengatasinya diperlukan metode analisis regresi tertentu, pada penelitian ini menggunakan metode Forward Selection, karena pada metodeini mengevaluasi semua kemungkinan model yang telah dibuat.

\section{a. Pengertian Kepadatan Penduduk}

Kepadatan penduduk menurut Samadi (2007) adalah perbandingan antara jumlah penduduk yang tinggal di wilayah tertentu dengan luas wilayah yang mereka tempati. Kepadatan penduduk ini dapat ditulis dengan persamaan sebagai berikut:

$$
\text { Kepadatan penduduk = Jumlah penduduk / Luas wilayah. }
$$

\section{b. Faktor-Faktor yang Berpengaruh Terhadap Kepadatan Penduduk}

1. Penduduk Pindah

Jumlah penduduk suatu daerah pasti akan mengalami perubahan, hal itu bisa disebabkan karena penduduk suatu daerah pindah ke daerah lain. Oleh karena itu jumlah penduduk pindah merupakan faktor penting yang berpengaruh terhadap kepadatan penduduk. Karena jika ada penduduk dari suatu daerah pindah ke daerah lain, maka pada daerah yang ditinggalkan akan mengalami pengurangan dari jumlah penduduk sebelum ada yang pindah. Perpindahan penduduk merupakan salah satu faktor dasar yang mempengaruhi kepadatan penduduk.

Transmigrasi adalah salah satu bentuk dari penduduk pindah. Kebijakan transmigrasi oleh pemerintah Indonesia selama orde baru bisa dikategorikan transfer penduduk. Perpindahan penduduk lainnya dapat pula karena imigrasi, seperti imigrasi dari Eropa ke koloni-koloni Eropa di Amerika, Afrika, Australia, dan tempat-tempat lainnya.

\section{Penduduk Datang}

Jumlah penduduk yang datang ke suatu daerah, merupakan faktor penting yang berpengaruh terhadap kepadatan penduduk. Setiap penduduk yang datang, akan menambah jumlah penduduk sebelumnya sehingga kepadatan penduduk akan bertambah. Pendudukan yang datang bisa saja orang yang dari luar wilayah datang ke wilayah kita yang bertujuan untuk menetap, belajar, atau bekerja, hal ini bisa menyebabkan meningkatnya jumlah penduduk.

\section{Penduduk Mati}

Kematian menjadi faktor yang penting terhadap kepadatan penduduk karena setiap terjadi kematianakan mengurangi jumlah penduduk dari jumlah sebelumnya. Berkurangnya jumlah penduduk menyebabkan turunnya kepadatan penduduk pada suatu daerah. Mortalitas atau kematian merupakan salah satu di antara tiga komponen demografi yang dapat mempengaruhi perubahan penduduk. Informasi tentang kematian penting, tidak saja bagi pemerintah melainkan juga bagi pihak swasta, yang terutama berkecimpung dalam bidang ekonomi dan 
kesehatan. Mati adalah keadaan menghilangnya semua tanda - tanda kehidupan secara permanen, yang bisa terjadi setiap saat setelah kelahiran hidup.

4. Penduduk Lahir

Kelahiran merupakan faktor yang akan sangat berpengaruh terhadap kepadatan penduduk, karena setiap terjadi kelahiran dalam suatu wilayah itu akan berakibat bertambahnya jumlah penduduk. Indonesia menerapkan pengendalian penduduk, yang dikenal dengan program Keluarga Berencana (KB). Program ini cenderung bersifat persuasif, namun dinilai berhasil menekan tingkatpertumbuhan penduduk Indonesia.

5. Luas Wilayah $\left(\mathrm{Km}^{2}\right)$

Luas wilayah suatu daerah mempunyai pengaruh terhadap kepadatan penduduk. Karena semakin luas suatu daerah, maka semakin besar peluang penduduk menempati daerah tersebut. Apalagi jika daerah tersebut luas dan dipenuhi dengan sarana dan prasarana yang memadai untuk menunjang kehidupan.

\section{c. Analisis Regresi Linear Berganda}

Analisis regresi linear berganda adalah suatu metode yang digunakan untuk menganalisis antara satu variabel terikat dengan beberapa variabel bebas (Drapper, Smith, 1992).Dalam regresi berganda terdapat satu peubah tak bebas yang akan dilihat hubungannya dengan dua atau lebih peubah bebasnya, misalkan peubah $Y$ dapat dinyatakan dengan fungsi-fungsi linier dari peubah $X_{1}, X_{2}, X_{3}, \ldots X_{n}$ yang diketahui dan terdapat faktor sisa. Model regresinya sebagai berikut

dengan

$$
Y_{i}=\beta_{0}+\beta_{1} X_{1 i}+\beta_{2} X_{2 i}+\ldots+\beta_{p} X_{p i}+€_{i}
$$

$i \quad=1,2,3 \ldots n$

$Y_{i} \quad=$ Nilai pengamatan yang ke- $i$

$X_{1}, X_{2}, \ldots X_{n}=$ Peubah bebas yang menentukan nilai pengamatan ke- $i$

$\beta_{1}, \ldots \beta p=$ Koefisien - koefisien regresi sebagian (parsial) untuk peubah $X_{1}, X_{2}, \ldots X_{n}$ secara berturut-turut.

$€_{i} \quad=$ faktor sisaan yang ke- $i$

$n \quad=$ banyaknya pengamatan.

Ada beberapa cara untuk pengujian kenormalan sisaan, yaitu :

1. Membuat plot pasangan $\left(e_{i} / S_{e}\right)$ yang telah diurutkan dari kecil ke besar terhadap presentasi kumulatif. Asumsi kenormalan dipenuhi jika hasil plot mendekati garis lurus dengan gradien $45^{\circ}$

2. Dengan menggunakan uji kenormalan Anderson-Darling. Jika nilai $P>0.05$ maka nilai sisaan mengikuti sebaran normal, sedangkan jika nilai $P<0.05$ maka nilai sisaanya tidak mengikuti pola sebaran normal.(Permadi, 1999).

\section{d. Multikolinieritas}

Dalam mendapatkan model regresi berganda terbaik maka persamaan regresi yang telah diperoleh terlebih dahuluharus diuji ada tidaknya multikolinearitas.Permasalahan yang sering dihadapi dalam menggunakan analisis regresi berganda adalah adanya multikolinieritas (ketergantungan antar variabel bebas) sehingga terdapat kesulitan untuk mengetahui pengaruh masing-masing variabel tidak bebas.

Melihat adanya multikolinearitas ada beberapa cara yakni: 
a. Dengan melihat elemen matrik korelasi. Jika korelasi antarvariabel bebas lebih besar daripada korelasi antara variabel bebas dengan variabel terikatnya maka terjadi multikolinearitas.

b. Metode lain untuk mengetahui multikolinearitas adalah menghitung besarnya multikolinearitas tiap variabel bebas dengan vaktor keragaman inflasi (Varian Inflation Faktor $=V I F$ ) didefinisikan sebagai berikut:

$$
V I F=\frac{1}{1-R j^{2}}
$$

$R_{j}^{2}$ adalah koefisien determinasi berganda dari peubah $X_{j}$ dengan semua peubah bebas yang lain. Apabila $V I F>10$ maka korelasi diantara variabel bebas sangat tinggi, dengan kata lain terjadi multikolinearitas . Jika terjadi multikolinearitas maka cara terbaik untuk mengatasinya adalahdengan menambah data pengamatan. Jika tidak mungkin untuk menambah data maka salah satu cara mengatasinya adalah dengan menghilangkan variabel yang menyebabkan multikolinearitas.

\section{e. MetodeForward Selection}

Dalam metode forward selection, pembuatan model terbaik dilakukan dengan menambahkan variabel satu per satu. Regresi linier sederhana memulai tahap awal dengan memasukkan 1 variabel prediktor. Tahap selanjutnya adalah menambahkan variabel prediktor baru sehingga ada 2 variabel prediktor dalam model. Pada analisis regresi dengan metode forward selection ini mengevaluasi semua kemungkinan model yang telah dibuat. Kemudian memilih model terbaik berdasarkan kriteria $R^{2}$ terbesar dan $S$ terkecil. Metode forward selection ini mengaitkan lebih dulu antara $Y$ dengan $X_{i}$ yang $R^{2}$-nya paling besar. Langkah berikutnya ditambahkan lagi $X$ berikutnya yang korelasi parsialnya paling besar dan akan berhenti bila ditambahkan lagi $X$ yang lain yang tidak menambah $R^{2}$ nya.

\section{METODE PENELITIAN}

\section{Metode Pengumpulan Data}

Metode pengumpulan data yang digunakan dalam penyusunan penelitian ini adalah sebagai berikut:

1. Arsip BPS (Badan pusat Statistik)

Data tersebut berisi tentang informasi-informasi yang dibutuhkan dalam penyusunan penelitian ini. Data tersebut meliputi arsip Program Jawa Timur yang berisi tentang data-data statistik Jawa Timur.

2. Literatur

Metode literatur yang mengacu pada studi kepustakaan sebagai bahan referensi yang berkaitan erat dengan penelitian ini. Adapun Panduan dalam mengerjakan software minitab adalah buku "Mengolah Data Statistik dengan Mudah MenggunakanMinitab 1" Oleh (Nur Iriawan : 2006)

\section{Jenis Data}

Data yang digunakan dalam penelitian ini adalah data sekunder. Data sekunder merupakan data yang diperoleh dari instansi yang bersangkutan, contoh dari data tersebut adalah dokumen-dokumen atau literatur yang ada di Badan Pusat Statistik. Data sekunder yang penulis gunakan adalah data jumlah penduduk 
datang, penduduk pindah, penduduk mati, penduduk lahir, dan luas wilayah.

Tabel 1. Sampel Data Kepadatan Penduduk Kota Blitar Pertahun Perkecamatan dan Faktor-Faktor yang Mempengaruhinya.

\begin{tabular}{cccccc}
\hline $\begin{array}{c}\text { Kepadatan } \\
\text { Penduduk }\end{array}$ & $\begin{array}{c}\text { Banyaknya } \\
\text { Penduduk } \\
\text { Pindah }\end{array}$ & $\begin{array}{c}\text { Banyaknya } \\
\text { Penduduk } \\
\text { Datang }\end{array}$ & $\begin{array}{c}\text { Banyaknya } \\
\text { Penduduk } \\
\text { Mati }\end{array}$ & $\begin{array}{c}\text { Banyaknya } \\
\text { Penduduk } \\
\text { Lahir }\end{array}$ & $\begin{array}{c}\text { Luas } \\
\text { Wilayah } \\
\left(\mathrm{Km}^{2)}\right.\end{array}$ \\
\hline 3329.07 & 32 & 76 & 27 & 41 & 1.0153 \\
5451.04 & 142 & 73 & 57 & 89 & 0.8824 \\
6523.79 & 56 & 52 & 39 & 48 & 0.5086 \\
2981.76 & 32 & 259 & 36 & 47 & 1.3321 \\
8541.81 & 256 & 191 & 138 & 131 & 1.4662 \\
3926.17 & 143 & 272 & 73 & 87 & 2.2620 \\
3140.64 & 75 & 252 & 49 & 73 & 2.4581 \\
8659.75 & 213 & 119 & 99 & 78 & 0.8670 \\
8649.93 & 156 & 156 & 51 & 53 & 0.6133 \\
7767.16 & 130 & 107 & 40 & 68 & 0.6803 \\
3124.79 & 88 & 142 & 42 & 69 & 1.5185 \\
1917.94 & 36 & 89 & 35 & 35 & 2.2300 \\
2650.02 & 98 & 159 & 58 & 71 & 2.6830 \\
1612.92 & 36 & 44 & 25 & 31 & 1.9102 \\
3200.28 & 46 & 99 & 21 & 34 & 0.8443 \\
2493.63 & 33 & 80 & 21 & 45 & 1.5307 \\
3553.40 & 73 & 96 & 42 & 74 & 1.2481 \\
4367.27 & 191 & 172 & 37 & 121 & 1.7954 \\
5478.64 & 334 & 233 & 84 & 122 & 2.1279 \\
5483.84 & 249 & 262 & 71 & 202 & 1.9552 \\
3855.09 & 198 & 385 & 74 & 98 & 2.6500 \\
\hline
\end{tabular}

Sumber: Badan Pusat Statistik Kota Blitar

Berdasarkan data pada Tabel 1dapat ditentukan suatu hubungan linier antara peubah respon, yaitu peubah tidak bebas dengan peubah-peubah bebas secara bersama-sama dengan analisis regresi linier berganda. Kepadatan penduduk sebagai peubah respon $Y$ (variabel terikat), sedangkan sebagai variabel $X$ (variabel bebas) adalah:

$X_{1}$ : jumlah penduduk pindah

$X_{2}$ : jumlah penduduk datang

$X_{3}$ : jumlah penduduk mati

$X_{4}:$ jumlah penduduk lahir

$X_{5}$ : luas wilayah $\left(\mathrm{Km}^{2}\right)$ 


\section{Flowchart}

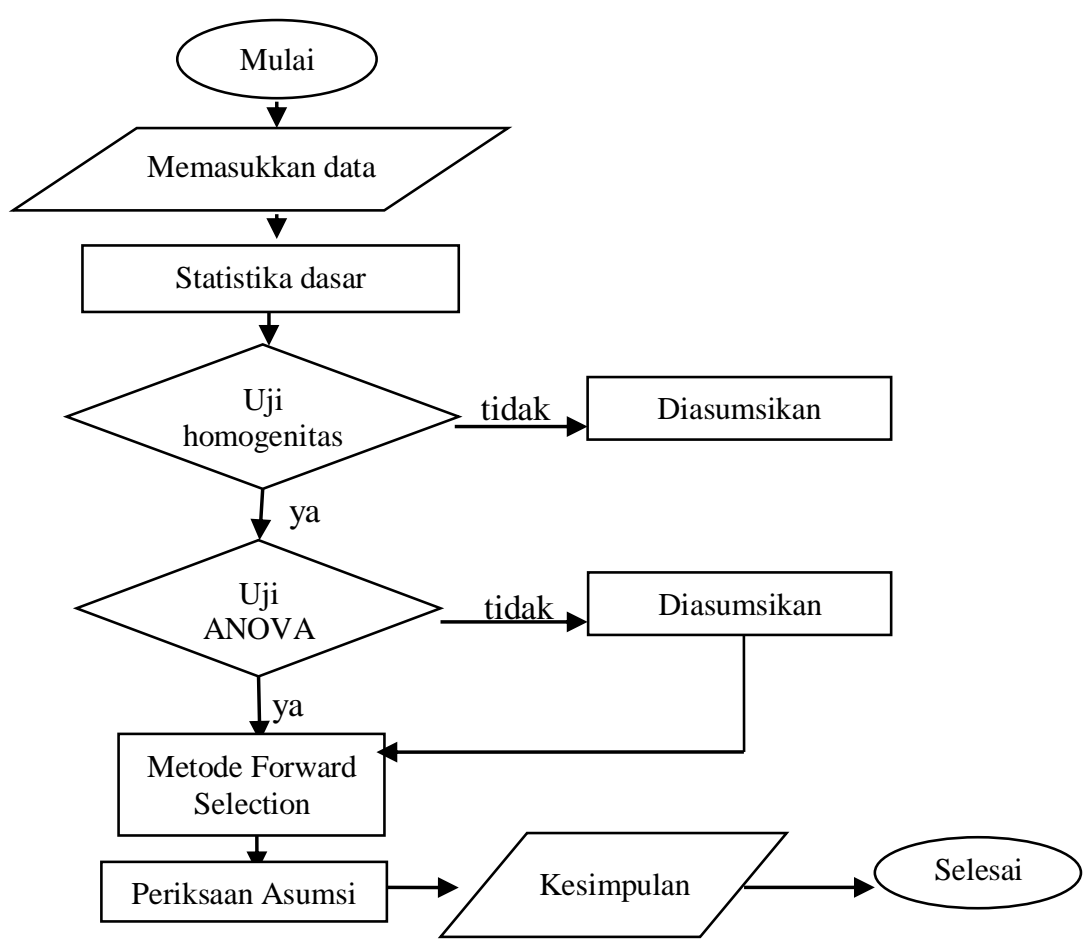

Gambar 1. Flowchart

\section{HASIL DAN PEMBAHASAN}

Berdasarkan pada data tabel 1. perlu dilakukan uji statistika dasar untuk mengetahui perlakuan data penelitian. Berikut adalah hasil plot Residual Model Diagnostics menggunakan minitab.

Residual Model Diagnostics
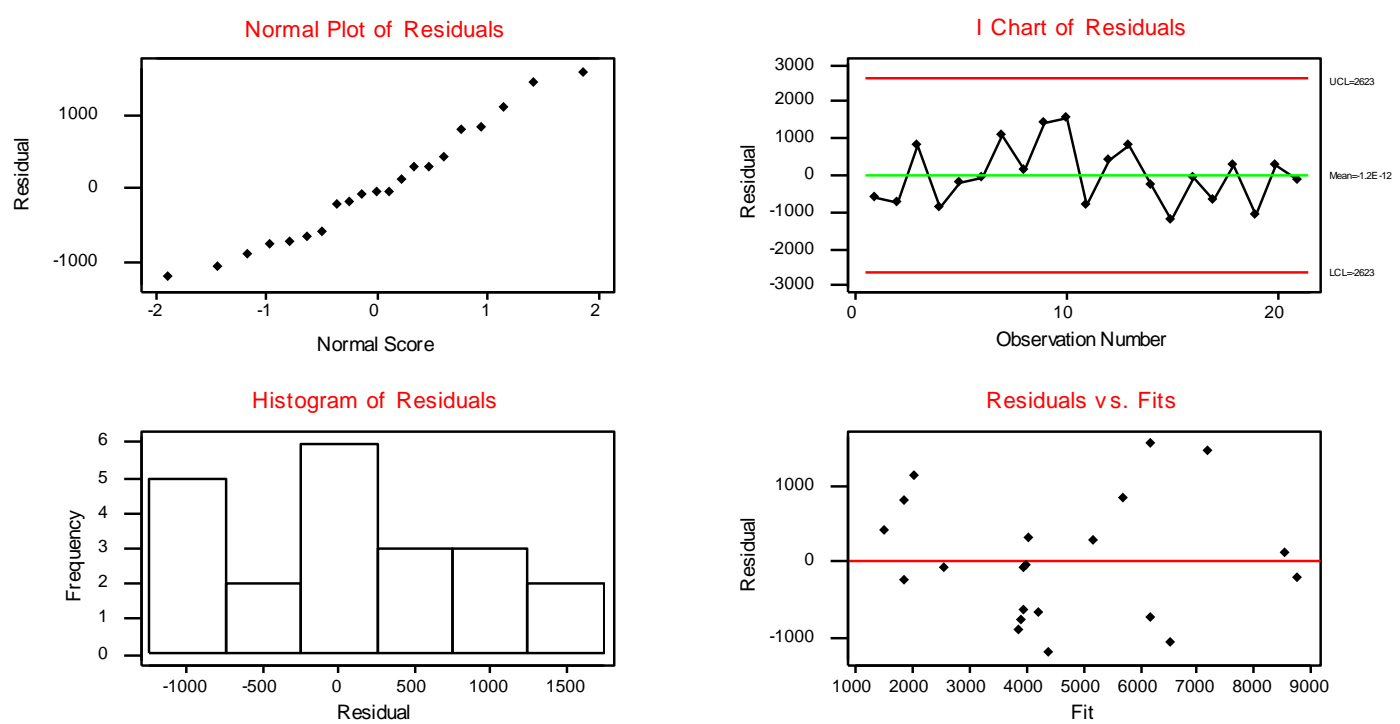

Gambar 2. Residual Model Diagnostics 
Dari Gambar 2 normal plot variabel residualkepadatan penduduk dan faktorfaktornya membentuk garis lurus dan sudutnya kurang dari $45^{\circ}$ dengan menggunakan uji Anderson Darling nilai $P$ adalah lebih besar dari 0,05 yaitu 0,583 sehingga $\mathrm{H}_{0}$ diterima yang menunjukkan bahwa sisaan mengikuti sebaran normal, ini berarti asumsi ini sudah terpenuhi sedangkan pada gambar I Chart of residual dan Residual vs. Fit menunjukkan ada atau tidaknya Gejala heteroskedastisitas dapat ditentukan dengan diagram scatter antara variabel $\mathrm{Y}$ prediksi (Fits) dengan variabel residual.Dapat disimpulkan tidak ada gejala heteroskedastisitas apabila plot menyebar merata di atas dan di bawah sumbu 0 tanpa membentuk sebuah pola tertentu. Diagram di atas dapat menyimpulkan bahwa tidak terdapat gejala heteroskedastisitas. Dan gambar Histogram dipelukan untuk menujukkan bahwa data berdistribusi normal dengan gambar menyerupai bel

menghadap ke Autocorrelation Function for RESI1

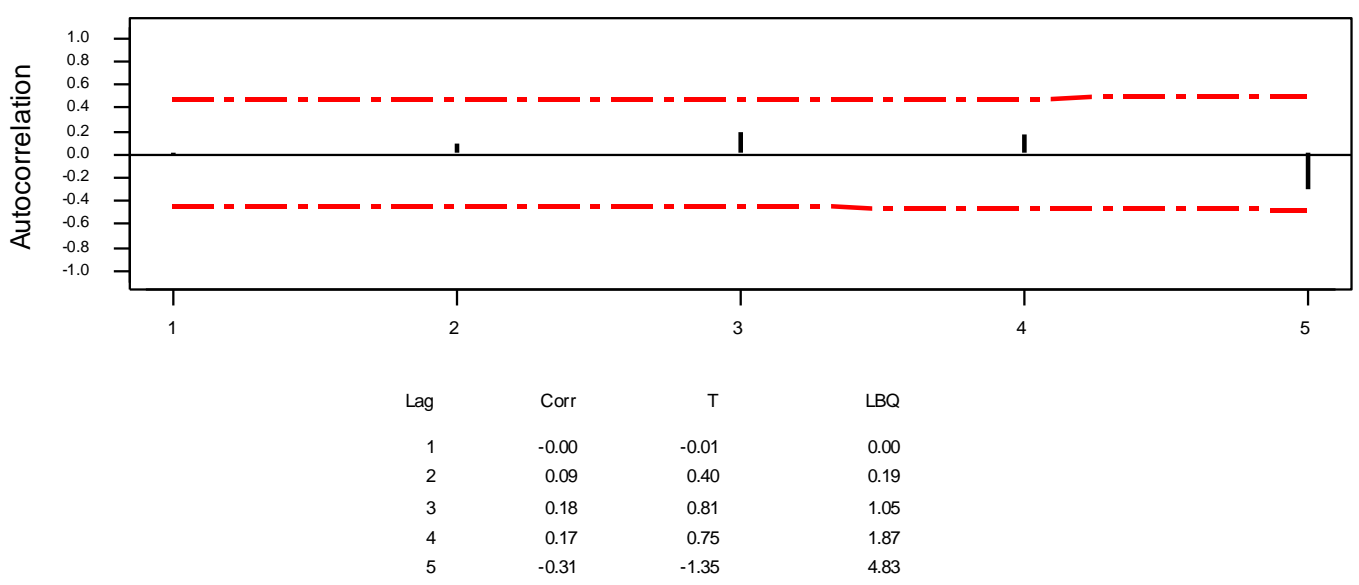

\section{Gambar 3. Grafik Autokorelasi Data}

Gambar 3. Merupakan grafik Autokorelasidigunakan untuk uji asumsi kebebasan sisa. Dari gambar menunjukkan bahwa nilai lag pertama signifikan sehingga dapat disimpulkan bahwa nilai sisaannya bersifat acak dengan demikian asumsi kebebasan sisaan terpenuhi. Pada pengujian kehomogenan nilai sisaan dapat disimpulkan bahwa ragam dari nilai sisaan bersifat homogen.

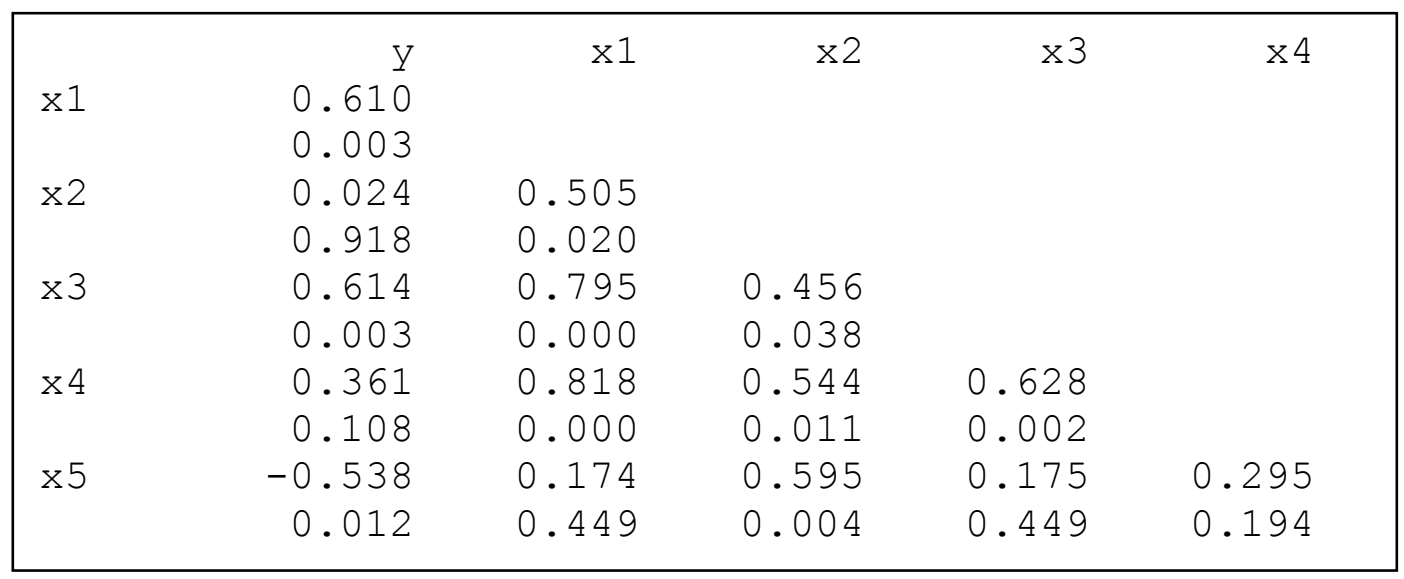




\section{Gambar 5. Korelasi antara Variabel terikat $Y$ dan semua variable bebas $X$}

Gambar 5 menunjukkan korelasi antara kepadatan penduduk dengan faktorfaktornya. Analisis korelasi, untuk mendeteksi adanya multikolinieritas antarvariabel prediktor, analisis dapat membuat korelasi antarvariabel prediktor. Pada tahap ini, tidak hanya membuat korelasi antarvariabel prediktor, tetapi juga membuat korelasi antara variabel prediktor dan variabel respons. Pada gambar 3 tertera bahwa korelasi antara varibel terikat $Y$ dengan $X_{1}$ sebesar 0.610 dengan nilai signifikasi sebesar 0.003 , korelasi antara varibel terikat $Y$ dengan $X_{2}$ sebesar 0.024 dengan nilai signifikasi sebesar 0.918, korelasi antara varibel terikat $Y$ dengan $X_{3}$ sebesar 0.614 dengan nilai signifikasi sebesar 0.003 , korelasi antara varibel terikat $Y$ dengan $X_{4}$ sebesar 0.361 dengan nilai signifikasi sebesar 0.108 , korelasi antara varibel terikat $Y$ dengan $X_{5}$ sebesar -0.538 dengan nilai signifikasi sebesar 0.003

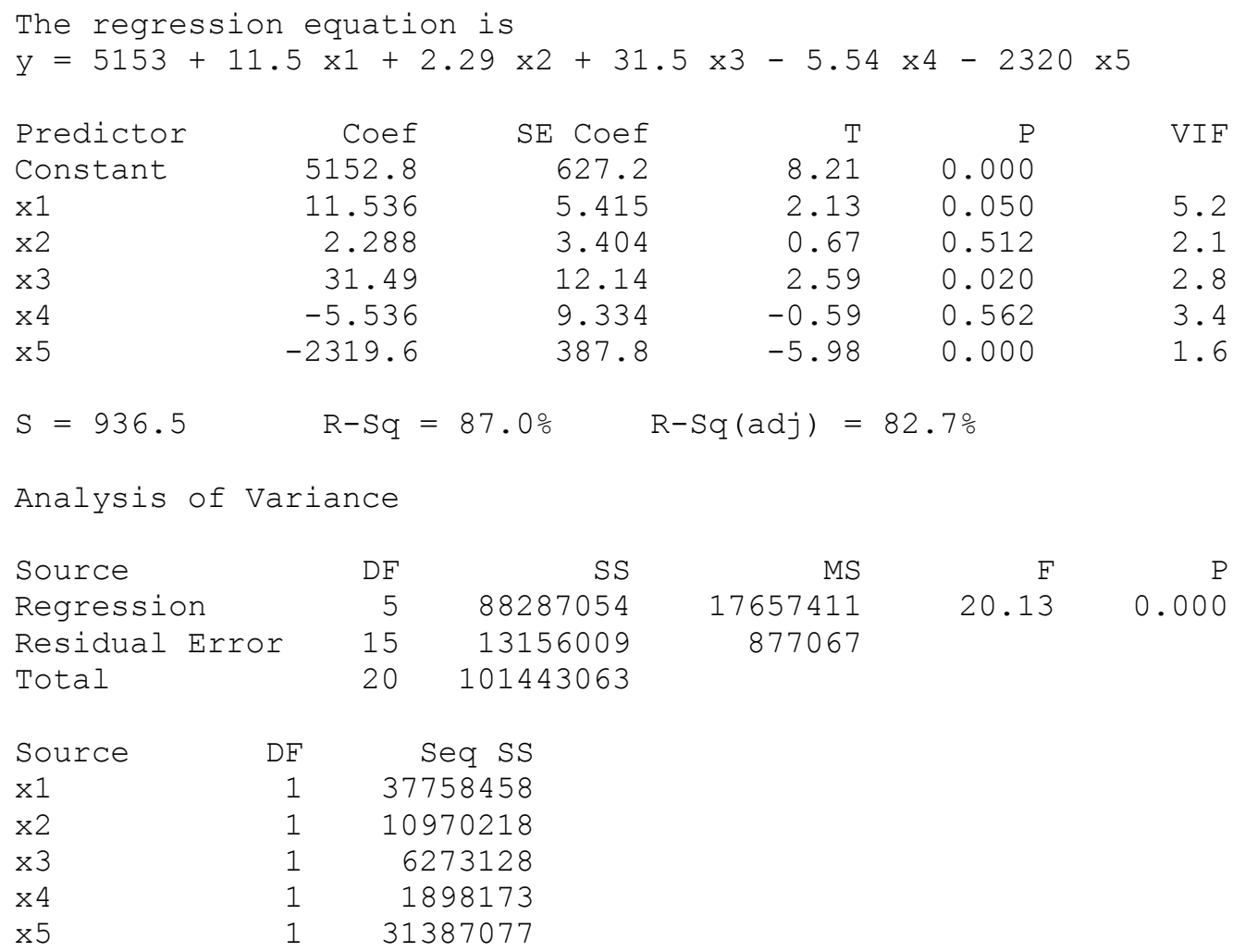

Gambar 6. Hasil Analisis regresi antara $Y$ dan semua peubah bebas

Setelah dilakukan analisis regresi, menghasilkan hubungan yang dinyatakan dalam bentuk persamaan sebagai berikut:

$$
Y=5153+11.5 X_{1}+2.29 X_{2}+31.5 X_{3}-5.54 X_{4}-2320 X_{5}
$$
dengan $R-S_{q}=87.0 \% R-S_{q}($ adj $)=82.7 \%$

Dari hasil analisis regresi linier berganda nampak bahwa peubah-peubah $X_{1}, X_{2}, X_{3}, X_{4}, X_{5}$ mempengaruhi jumlah penduduk. Hal ini dapat dilihat dari signifikansi $P=0.000<0,05$. Dengan demikian dapat diambil kesimpulan bahwa jumlah penduduk pindah, penduduk datang, jumlah penduduk mati, jumlah penduduk lahir, dan luas wilayah mempengaruhi kepadatan penduduk tiap tahunnya sebesar $87,0 \%$ sedangkan sisanya sebesar $12 \%$ dipengaruhi oleh peubah lainnya. Dari hasil analisis regresi tersebut menunjukkan tanda terjadinya 
multikolinieritas, dapat dilihat dari matriks korelasi yang menunjukkan bahwa korelasi antar peubah bebas lebih besar daripada korelasi antara peubah bebas dengan peubah terikatnya. Korelasi antara $X_{1}$ dan $X_{5}$ lebih besar dari korelasi antara $Y$ dan $X_{5}$, yaitu $0.174>-0.538$, dan terjadi perubahan tanda, sehingga dapat disimpulkan bahwa terjadi kasus multikolinieritas.

Sehingga permasalahan multikolinieritas ini harus diatasi, selanjutnya akan digunakan metode Forward Selection untuk mengatasi masalah multikolinieritas tersebut.Forward Selection adalah salah satu cara lain untuk mengatasi masalah multikolinieritas yang terjadi, yaitu dengan mengaitkan lebih dahulu antara variabel $Y$ dengan variabel $X_{i}$ yang $R-S_{q}$ nya paling besar. Dalam Forward Selection, pembuatan model terbaik dilakukan dengan menambahkan variabel satu persatu. Regresi linier sederhana memulai tahap awal dengan memasukkan 1 variabel prediktor. Tahap berikutnya adalah menambahkan variabel prediktor baru sehingga ada 2 variabel prediktor dalam model. Penambahan tersebut diulangi sampai semua variabel masuk ke dalam model.Hasil Forward Selection untuk lebih jelasnya dapat dilihat pada gambar 5 di bawah ini.

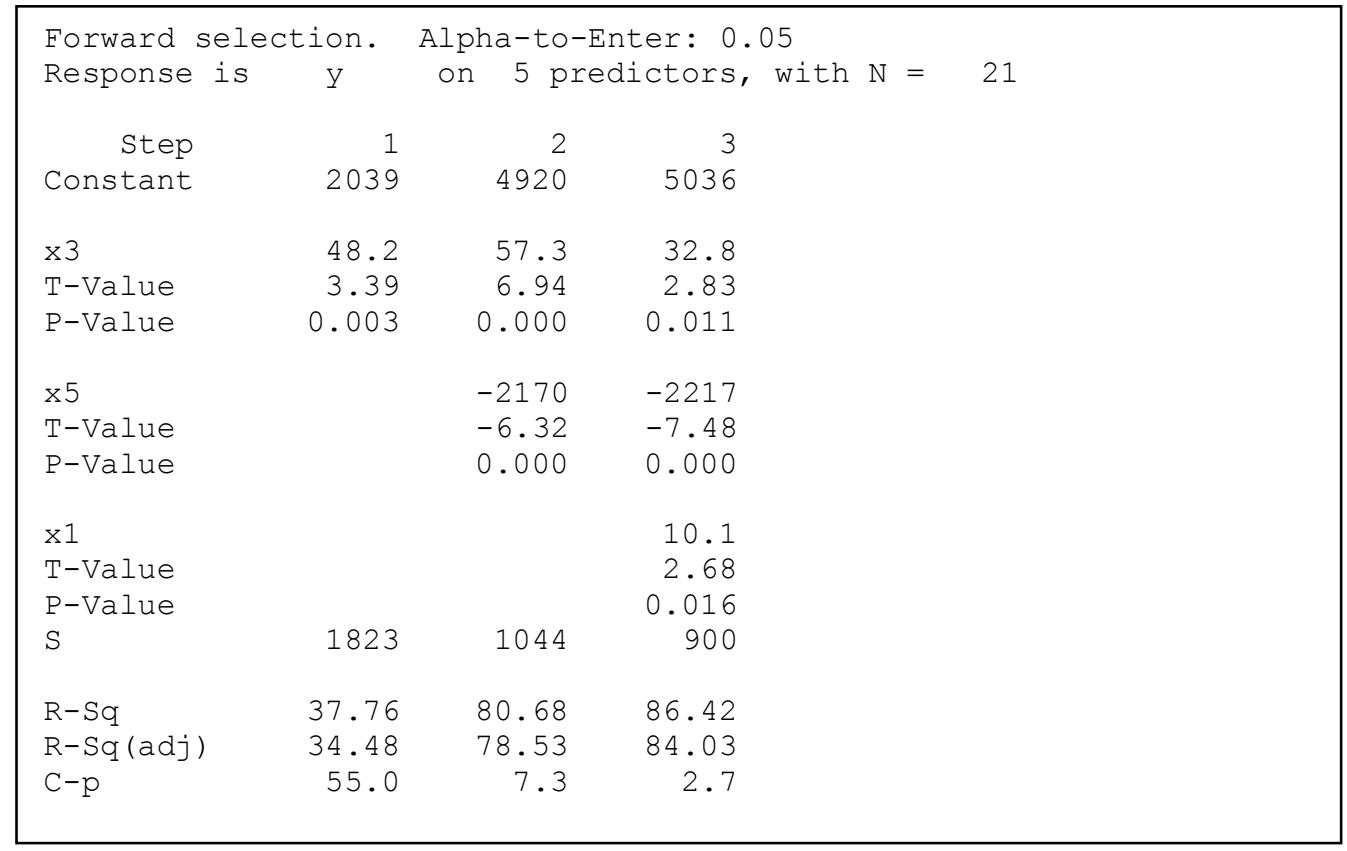

\section{Gambar 7. Hasil Regresi Forward Selection}

Dari hasil tersebut didapatkan model terbaik yang sesuai dengan kriteriakriteria yang telah ditentukan dan tidak terjadi multikolinieritas lagi. Maka model terbaik yang digunakan adalah model regresi dengan 3 variabel bebas. Persamaannya adalah :

$$
Y=5036+10.1 X_{1}+33 X_{3}-2217 X_{5}
$$

dengan $R-S_{q}=86,42 \quad R-S_{q}(a d j)=84,03$

Karena korelasi antar variabel bebas tidak ada yang lebih tinggi dari korelasi variabel bebas dengan peubah respon, maka persamaan yang dihasilkan sama dengan menggunakan regresi linier berganda, dengan $F_{\text {hitung }}$ sebesar 36.07sehingga $F_{\text {hitung }}$ jelas lebih besar dari $F_{\text {tabel }}\left(F_{0.05 ; 3 ; 17}\right)$ yaitu 3.20 atau nilai $P<\alpha$ yaitu $0,000<0,05$, ini berarti bahwa data sudah signifikan. Maka menolak $\mathrm{H}_{0}$ dan dapat dikatakan bahwa pengaruh variabel bebas berarti terhadap model. 
Dari model prediksi tersebut model terbaik yang dihasilkan melalui metode regresi Forward Selection mampu menjelaskan keragaman data yang sama yaitu sebesar $86,42 \%$. metode Forward selection dapat digunakan untuk menjawab masalah pada penelitian ini dan menghasilkan model yaitu $Y=$ $5036+10.1 X_{1}+33 X_{3}-2217 X_{5}$.

\section{KESIMPULAN}

Berdasarkan hasil dari pembahasan, maka kesimpulan yang dapat diambil adalah sebagai berikut :

1. Data kepadatan penduduk dan faktor-faktor yang mempengaruhinya, ternyata mengalami kasus multikolinieritas. Sehingga perlu diatasi, dalam penelitian ini digunakan metode Forward Selection. Sehingga bisa diperoleh model persamaan regresi yang terbaik yaitu $Y=5036+$ $10.1 X_{1}+33 X_{3}-2217 X_{5}$ dengan $R-S_{q}=86,42 \%$.

2. Dari pembahasan tersebut dapat diketahui bahwa faktor-faktor yang paling berpengaruh terhadap kepadatan penduduk di Kota Blitar khususnya adalah jumlah penduduk pindah, penduduk mati, dan luas wilayah.

\section{SARAN}

Dalam perkembangan ilmu statististik dan penggunaanya maka disarankan pada penelitian-penelitian yang sejenis untuk :

1. Menggunakan metode lain sebagai pembeda hasil yang didapatkan oada metode Forward selection ini.

2. Menambah jumlah jumkah faktor peubah bebas yang mempengaruhi untuk melihat kembali hubunganya dengan faktor- faktor peubah tidak bebas

\section{DAFTAR RUJUKAN}

Draper, N., \& Smith, H. (1992). Analisis Regresi Terapan. Jakarta: Gramedia Pustaka.

Iriawan, N. (2006). Mengolah Data Statistik dengan Mudah Menggunakan Minitab 14. Yogyakarta: ANDI.

Permadi, H. (1999). Teknik Analisis Regresi. Malang: JICA.

Samadi. (2007). Geografi 2: SMA kelas XI. Jakarta: Quandra. 